\title{
The British and the German financial sectors in the wake of the crisis: size, structure and spatial concentration
}

\author{
Dariusz Wójcik and Duncan MacDonald-Korth \\ School of Geography and the Environment, Oxford University, \\ South Parks Road, OX1 3QY Oxford, UK \\ dariusz.wojcik@spc.ox.ac.uk
}

\begin{abstract}
We use employment data for 2008-12 to analyse the impact of the subprime and Eurozone crises on the British and German financial sector. In the UK the sector contracted and its spatial concentration increased across regions and urban hierarchy, with London as the sole winner. In Germany there has been no contraction overall, and no significant change in the spatial distribution of financial employment. We argue that while in both countries forced consolidation and financial re-regulation have acted as centripetal forces, in Germany they have been offset by strong regional and local banking, underpinned by a decentralized state.
\end{abstract}

Keywords: crisis, financial centres, UK, Germany

JEL codes: G20, P16, R11, R38 


\section{Introduction}

The US subprime crisis, which infected the world economy in 2007-8, and the Eurozone crisis that ensued, have been reshaping the geography of finance. Financial institutions, with large banks in the lead, have struggled from the legacy of toxic assets, shrinking markets, lawsuits resulting in individual fines reaching billions of dollars, and mounting new regulation, turning competition among financial firms and centres into a negative-sum game. Three of the four largest British banks - RBS, Lloyds and Barclays - have scaled down their operations, particularly in international and investment banking. In May 2014 Barclays, for example, announced moving $£ 400 \mathrm{bn}$ of assets into a non-core unit and laying off 14,000 people (Arnold and Sharman, 2014), and in October Lloyds announced cutting 9,000 jobs and shutting 200 branches (Dunkley, 2014). Since 2012, HSBC has been the only UK-headquartered bank ranked in the top 10 in the world according to tier-1 capital (The Economist, 2014). Some argue that the retreat of British banking champions matters little, as the Wimbledon effect prevails, with the UK providing the court and foreigners playing, sustaining the future of London as the capital of global finance. Others however, point to London losing its top position in the Global Financial Centres Index (GFCI) to New York in March 2014 for the first time in the 7-year history of the ranking (Z/Yen, 2014) as indicative of the City's declining influence.

The picture of the financial sector in Germany, while being affected more directly by the Eurozone crisis, appears less pessimistic. Deutsche Bank, with the largest asset base of any EU bank, has thus far defied the trend of downsizing and retreating from international and investment banking. In June 2014 it raised $€ 8 b n$ in capital from existing shareholders and the Qatar royal family. This move 
was described as part of a strategy to be "the last man standing after a post-crisis shake-out among Europe's other global, full-service investment banks", and "Europe's last viable competitor to the big Wall Street banks" (Schäfer and Ross, 2014). To add to optimism in Frankfurt, in November 2014, the European Central Bank became the regulator of all banks in the Eurozone, as part of the introduction of the Banking Union. On the other hand, Frankfurt's GFCI rank has fallen from 6 in 2007 to 16 in September 2014, when in Europe, the German financial capital trailed not only London, but also Zurich, Geneva, and Luxembourg (Z/Yen, 2014b).

The subprime and Eurozone crises have impacted the geography of finance beyond the shifting landscape of financial centres. According to some observers new regulation at supra- and national levels, focused on stability, leads to a falling degree of global financial integration, also referred to as "balkanization" of finance (The Economist, 2014b). Such regulation can take the form of incentives for retail and small business lending and disincentives for wholesale and investment banking (for example through ring-fencing of retail from investment banking); or requirements that foreign banks operate in the form of subsidiaries, holding their own capital and subject to host country regulation, rather than branches, which can move capital and resources freely across countries and are subject to home country regulation only. If balkanisation of finance is indeed happening, the question is how far it will go. Could it lead to finance becoming more regionalized at subnational levels in addition to becoming more nationalized?

In this context, the objective of the paper is to analyse the impact of the subprime and Eurozone crises on the financial sector in Germany and the UK. 
These countries host the two largest financial sectors and leading financial centres in the EU, but have also been described as having fundamentally different financial systems. While the UK is the archetype of capital-market based, centralized and spatially concentrated finance, Germany has played a similar part as a bank-based, decentralized and spatially dispersed system. In this sense, the paper extends well-established literature in political economy and economic geography comparing the two financial systems and their footprint (Verdier, 2002; Klagge and Martin, 2007). It also offers a contribution to emerging literature on the economic geography of financial crises (Martin, 2011).

Specifically, we ask how the size, structure and spatial concentration of the financial sector in Germany and the UK have changed between 2008 and 2012. While spatial concentration is the central focus of the paper, questions of size and structure complement it and are crucial to understanding the magnitude and nature of change. The more change in size and structure (institutionally and by subsectors) we observe, the larger the potential for change in geographical footprint and spatial concentration. The analysis of size, structure and spatial distribution is based on employment data, arguably the only type of data available to allow a systematic geographical analysis. In addition, where possible, the analysis has been augmented with the use of data on financial stocks, flows and institutional structures.

The findings demonstrate stark contrasts between Germany and the UK. In the wake of the crises both countries have exhibited considerable inertia in terms of financial centre hierarchy, and growth of asset management and other financial services at the expense of banking and insurance. Here, however, 
similarities end. In Germany, financial sector employment grew by $1 \%$, while in the UK it shrunk by $8 \%$. This is driven to a large extent by a better performance of the German economy in terms of GDP and employment, but it also reflects a deeper fall in the share of finance in total employment in the UK than in Germany. The most striking differences are found with regard to spatial distribution. While in Germany the spatial concentration of finance across financial centre hierarchy and regions has hardly changed, the UK finance has become more geographically concentrated. By 2012 London had more than recovered in terms of financial employment, with large losses shared across regional financial centres, and even larger losses in peripheral areas further down the financial centre hierarchy.

Our empirical results support a broader theoretical argument that institutional structures of financial systems are closely interlinked with their geography (Clark and Wójcik, 2007). Continued regionalization of German finance may be partly ascribed to the general preservation of jobs in the financial sector and the wider German economy, but the relative strength of regional and local banks in Germany has played an important part. While German large and international banks, operating mainly out of Frankfurt, have suffered most from both the subprime and Eurozone crises, regional and local banks have been more insulated from them, and continued to expand their activities in the post-crisis era, to the benefit of small and medium sized companies, and a more balanced geography of German finance. In contrast, the growing concentration of the British financial sector in London has been driven by consolidation, with London-based banks taking over provincial institutions, and new regulation fuelling demand for London-based compliance jobs. The growing concentration 
in London also reflects the Wimbledon effect, whereby London continues to attract international finance, irrespective of the deteriorating international profile of British banks. In short, despite common pressures, the British and German financial systems have reacted differently to the crises. While the British system, has become even more uneven, the geography of the German system has proven more stable.

\section{Geography of financial systems}

Embarking on an analysis of the spatial distribution of financial employment, we assume that the spatial structure of financial systems matters (Klagge and Martin, 2005). This view of the world stands in contrast with the conventional (neoclassical) economic theory which claims that finance has no impact on economy of production (Mishkin, 2007). To compare financial systems in Germany and the UK, we need to combine economic geography with political economy, in a framework that takes both space and institutions seriously. Such approach is offered by Verdier (2002) in a model that starts with agglomeration economies and information asymmetry as two major forces shaping the geography of financial systems. Agglomeration economies act as a centripetal force, making financial centres to grow at the expense of peripheries. Information asymmetry has a centrifugal effect whereby lenders need to be close (physically and/or socially) to borrowers. Information asymmetry however does not apply to the funding/liabilities side of banks, which means that financial centre banks can avoid smaller size, less liquid investments and credit in the periphery, while draining it of savings. With markets left to their own devices, centripetal forces win, and the spatial concentration of a financial system grows, 
creating inequalities in access to credit and investment. According to Verdier, the only way to prevent this process is state decentralization, with strong local governments protecting local and regional financial institutions: “(...) local banks and firms have solely the local government connection as viable political channel, and this only in those countries where local governments enjoy a modicum of political power - in decentralized countries" $(2002,27)$. In his framework, state decentralization explains not only spatial concentration, but also the degree of intermediation, internationalization and specialization of financial systems. More decentralized states are argued to have financial systems that are more bank- than market-based, since marketable securities in contrast to loans depend more on liquidity and centralised secondary markets; less internationalized, since their financial centres attracting international financial activity are weaker; and less specialized, with more reliance on universal banking, since strong local and regional banking limit the benefits of product specialization.

Germany and the UK play a key part in Verdier's argument. Echoing the work of Gerschenkron (1962), and Zysman (1983) he observes: "The marketbased versus bank-based dichotomy was the defining typology of the nineteenth century. Financial systems lined up along a continuum bounded by England at one end and Germany at the other" $(2002,217)$. Concluding his analysis of the evolution of financial systems in 20 countries from mid-19th $c$. until the late 1990s, he states: "The two benchmarks, therefore, are the British and German cases again: British finance is high on all dimensions - concentration, internationalization, securitization, and specialization - whereas German finance is low on all four" $(2002,218)$. With state decentralization in Germany remaining 
the key explanation for the difference (with approx. 90\% of government revenue managed centrally in the UK, and $50 \%$ in Germany), Verdier also considers the impact of common law, which by strengthening the rights of investors facilitates the development of concentration-prone capital markets. In addition, he considers privately funded as opposed to state funded pensions, which fuel securitization to feed the demand of pension funds for marketable securities, thus facilitating concentration. Both in terms of legal and pension systems, the difference between Germany and UK is clear (La Porta et al., 1998; Clark, 2000). To be sure, while the paper focuses on financial systems, we have to appreciate that they do not exist in a vacuum, but are part of broader historically-rooted economic systems or capitalisms. In this regard, the German bank-based financial system is presented as part of the co-ordinated market economy of Germany, in contrast to the market-based finance of the UK as a building block of a liberal market economy (Hall and Soskice, 2001). Small and medium size firms play a bigger part in the German than the British economy, and their reliance on credit and long-term and mostly local house-bank relationships are key factors underlying decentralization of the German financial system.

Verdier's framework, while exceptional in its parsimonious but open fusion of economic geography and political economy, presents three shortcomings for the purposes of this paper. First, when considering spatial concentration, it seems to underplay the possibility that with costs of transport and communication falling to very low levels, and diseconomies of agglomeration rising at high levels of concentration, the latter may decline, creating the inverted U-shape pattern proposed by New Economic Geography (Fujita, Krugman and Venables, 1999). Grote (2008) provides some evidence for 
the pattern, demonstrating that the concentration of foreign bank offices across Germany, and in Frankfurt in particular, increased sharply after the establishment of the German central bank in the city in 1948, but since mid 1980s it has slightly decreased. Engelen and Grote (2009) refer to this process as renewed regionalization of German finance. Results consistent with this observation are also found in research on the connectivity and status of German cities as centres of financial and other business services (Hoyler, 2011; Volgman, 2014). The second shortcoming concerns the significance of change from the late 1990s until 2008, with accelerated European (and global) financial integration. In his book, Verdier himself pondered whether the dichotomy between financial systems in terms of spatial concentration, intermediation, internationalization, and specialization would survive. With the EU promoting the model of universal banking (following deregulation in the US), differences in terms of specialization have been fading away for a long time (Leyshon and Thrift, 1997). Privatisation of state-owned companies such as Deutsche Telekom and their flotation on stock markets, alongside the Neuer Markt boom of late 1990s, which brought hundreds of companies and thousands of investors to stock markets, contributed to securitization. The expansion of Deutsche Bank into global investment banking has added to the internationalization of German finance (Hendrikse and Sidaway, 2014). In some respects the British and German financial systems have undergone convergence, with the UK embracing universal banking, while the German system became more market-based and internationalized. Put differently, German firms, including Deutsche Bank and high-tech firms, have to some extent bypassed national institutions to tap into global markets and viceversa (Clark and Wójcik, 2007; Dixon, 2012). In a sense, out of the four 
parameters of financial systems outlined by Verdier, one that we could be most sure about with regard to the contrast between Germany and the UK on the eve of the subprime crisis was spatial concentration (Klagge and Peter, 2011).

This leads us to the shortcoming that concerns the impact of financial crises on spatial concentration. Unfortunately, Verdier covers periods of financial expansion only (1850-1913 and 1960-2000), and to the best of our knowledge no theoretical models are available focusing on spatial concentration of finance in conditions of crisis. Relevant empirical evidence is available on the US financial sector following the savings and loan crisis of late 1980s, and on the UK in 1990-1, suggesting that crises led to more concentration, mainly through institutional consolidation (Leyshon and Thirft, 1997; Warf and Cox, 1996). This leaves us to build our hypotheses on spatial concentration of the financial sector in Germany and the UK between 2008 and 2012 in a non-parsimonious manner, focusing on identifying centripetal and centrifugal forces across economic, political, and cultural realms.

Starting with economic factors, the crisis affecting the German financial sector has been less severe than in the UK. In contrast to the UK, Germany did not experience a house price bubble or a credit boom in late 1990s and early 2000s (Martin, 2011), which more than compensated for closer links between German banks and the most Eurozone-crisis stricken economies of southern Europe (Bassens et al., 2013). By mid 2010 the value of assets written off balance sheets of British banks was approx. €500bn, twice larger than that in Germany (Helaba, 2010). With Germany maintaining a better sovereign rating than the UK, funding for German financial institutions on international markets has been cheaper. A more employee-friendly labour market regime in Germany would 
cushion the impact of the crisis on employment further. Staff cutbacks are commonly negotiated with work councils and unions, and part-time work as well as government subsidies are used as alternatives to cutting personnel. As a result, the impact of the crisis on the German labour market has been documented as mild (Möller, 2010; Zagelmayer, Heckmann, Kettner, 2012). What made the German economy relatively well-prepared for the crisis was also the fact that the growth of labour costs have been controlled and limited since the 1990s (Stockhammer, 2011). Altogether, basic economic factors suggest a milder impact of the crises in Germany than the UK, which in itself would create a larger scope for changing spatial distribution and concentration of the financial sector in the UK.

To advance our hypotheses, we need to consider the institutional structure of financial systems. As the subprime crisis spread across Europe through international wholesale markets, and credit to the Eurozone-crisis stricken European periphery also involved mainly large internationally oriented banks, we could expect the concentration of job losses in large international financial centres like London and Frankfurt. This centrifugal effect however, has to be moderated with the following considerations. Some institutions based outside of financial capitals, including RBS, HBOS, Northern Rock as well as WestLB and IKB in Düsseldorf had also tapped into wholesale funding and investment in subprime assets on international markets, in an attempt to compete with more established financial centre banks (Marshall, 2013; Marshall et al., 2012; Martin, 2013; Lewis, 2011). Second, in the case of UK, but not Germany, overextension of credit prior to the crisis, would imply overstretched balance sheets and pressure to cut costs throughout the system, including 
regionally- and locally-oriented banks (Cooper and Larkin, 2008). Third, in the process of restructuring, we would expect consolidation in the financial sector, with larger institutions taking over smaller ones, and trimming their branch networks, resulting in a growing spatial concentration, as witnessed during previous crisis episodes (Leyshon and Thrift, 1997). The institutional feature that would moderate such process in Germany is the prevalence of over 400 government-controlled savings and state banks (Landesbanken), which together with over 1100 cooperative banks, dedicated to mobilizing local and regional savings for local and regional credit, account for the majority of employment and credit generated by the financial sector (Gärtner and Flögel, 2014). Finally, considering the subsectors of finance, we would expect a stronger impact of the crises on banking than on insurance or asset management.

The main political factor at play is government intervention. Both countries witnessed bank bailouts. While in Germany their magnitude was lower, arguably government intervention in Germany was focused more on stabilizing regional banks and maintaining the access of small and medium sized companies ("Mittelstand") to credit. In contrast to the UK, where financial support in response to the crisis was all orchestrated by the central government and the Bank of England, in Germany local governments played an important part alongside KfW, a government-owned development bank, with a mandate to support the "Mittelstand" (Helaba, 2010). With both countries being members of the EU, it is difficult to judge where new regulation has been more radical or stricter. On the one hand, there is more institutional change in UK financial regulation, with a shift of regulation from the FSA to the Bank of England, and the planned ring-fencing of retail banking in the UK going further than requirements 
on the isolation of proprietary trading from the rest of banking business in Germany. On the other hand, in contrast to Germany, the UK government opposes the Financial Transactions Tax, and has introduced rather flexible interpretation of rules on bankers' bonuses. One effect of new regulation, however, should be common. In both countries it generates large demand for additional employment in regulatory agencies, and in compliance and risk management departments of private financial institutions (McGrath, 2014). As regulatory agencies are located predominantly in leading financial centres, and new regulation addresses primarily large financial institutions of systemic significance, employment related to new regulation is likely to act as a powerful centripetal force in the post-crisis era. While in Germany some regulatory agencies are located outside of Frankfurt, the consolidation of European financial regulation in the ECB attracts financial employment to Frankfurt.

Related to the issue of regulation are cultural factors related to image and reputation of leading financial centres, affecting their attractiveness to financial firms and professionals. Commenting on New York taking over the top GFCI spot, Wright $(2014,7)$ claimed that “London's fall from grace can partly be attributed to the number of scandals that have emanated from the City in the past couple of years: rate swaps, the London Whale, Libor and foreign exchange rigging to name only the most mendacious". Frankfurt has not suffered from such damage and plays on this advantage advertising itself as a centre of stability and quality (International New York Times, 2014). If we are to take research on connectivity and complementarity among leading financial centres seriously, we should not expect much divergence between the paths of London and Frankfurt since 2008 (Faulconbridge, 2004; Beaverstock et al. 2001). To a large extent the position of 
different financial centres is the footprint of competition among international financial firms rather than direct competition among financial centres themselves. Frankfurt is important as a gateway to Europe's largest economy and Eurozone, while London remains a gateway to global finance. Many if not most financial firms with truly international ambitions are present in both London and Frankfurt, and would not consider a choice between one or the other, even under cost pressures generated by the crisis. As a reflection of this fact, the number of foreign bank offices in Frankfurt is not much smaller than the corresponding figure for London, although employment in the latter is much larger (Grote, 2008).

Finally, we should remember that the changing attractiveness of different financial centres would not necessarily translate into significantly and quickly changing geography of financial employment. Despite the unbundling of financial industry value chains (Grote, Lo and Harrschar-Ehrnborg, 2002), and increasing international and interregional trade of financial services, a large part of employment in finance still relates to basic banking and insurance services, with their distribution mirroring the distribution of population and businesses. This Christallerian feature of financial services implies considerable inertia in national financial centre hierarchies (Parr and Budd, 2000). Long-term historical studies also highlight that changes at the top of international financial centre hierarchy are very slow (Cassis, 2006), in contrast to indices such as GFCI which intentionally and understandably exaggerate change. Thus, studying change in the spatial distribution of the financial sector, the default hypothesis should be to expect slow change. 


\section{Data and methods}

Using data on employment in the financial sector, we define the latter as consisting of three categories of the Standard Industrial Classification: monetary intermediation, activities of holding companies, trusts, funds and similar activities, other activities except insurance and pension funding (category 64); insurance, reinsurance and pension funding (65); activities auxiliary to financial services and insurance activities (including insurance agents and brokers, securities and commodity brokerage, and investment advice; category 66). We refer to them shortly as banking, insurance, and auxiliary financial services. The German data come from the Federal Employment Agency (Bundesagentur für Arbeit) and cover all employees who are obliged to pay social insurance contributions, thus excluding self-employed and civil servants. The UK data come from the Business Register and Employment Survey of the Office of National Statistics, covering all employees and working proprietors, but excludes selfemployed and voluntary workers. As such the sources underestimate the size of the sector, but not in a way that would distort analysis across space and time.

The data cover the period of 2008 to 2012. German data stand for June $30^{\text {th }}$ of each year, the British for September $14^{\text {th }}$. Due to changes in industrial classification, data prior to 2008 are not fully comparable with data from 2008 onwards either for Germany or the UK. The year of 2012 was the latest that data were available for at the time of writing the paper. In what follows we conduct the analysis of employment data at two levels. In section 4 we compare the absolute and relative size and structure of the financial sector between Germany and the UK and their change over time. Section 5 presents the core findings of 
the paper, exploring the changing spatial distribution of German and British financial services across the hierarchy of financial centres and regions.

\section{Changing size and structure at the country level}

In 2012 finance employed 1,004k people in Germany, 14k more than 4 years earlier, while in the UK the sector shed $88 \mathrm{k}$ jobs or $8 \%$ of its 2008 level of 1,133k. Throughout the period, Germany has maintained financial employment higher than in 2008 (figure 1). The temporal pattern of employment in the sector makes sense in the context of crisis events. The British figure drops sharply in 2009 and continues to fall in 2010, while the German figure declines only in 2010. Arguably, the US subprime crisis of 2007-9 affected the UK economy and finance more quickly and forcefully than Germany's, while the Eurozone crisis that broke out in late 2009 affected both countries. In 2011-2 finance in both countries shows signs of a weak and fragile recovery, which can be understood considering continued uncertainty about the Eurozone economy, weak recoveries in international financial markets, and mounting financial regulation at national and supranational levels. Contrast between UK and Germany also makes sense in the light of general employment and GDP changes. In 2012 the UK GDP (in constant prices) was still over 2\% below its 2008 level, while in Germany it was nearly 3\% higher. Difference in employment change was even larger, with British 2012 employment still 3\% behind the pre-crisis level, and 5\% above it in Germany. The milder impact of GDP changes on employment in Germany is most likely the result of its more protective labour market regime. Understandably, the crises have affected the financial sector more than the rest of the economy in both countries. Consequently, between 2008 and 2012 the share of finance in 
total employment fell from $4 \%$ to $3.8 \%$ in the UK, and from $3.6 \%$ to $3.5 \%$ in Germany.

$$
\text { <insert figure } 1 \text { around here> }
$$

Figure 2 and 3 chart the changing structure of financial employment by subsector. Figure 3 clearly demonstrates the difference between a more bankbased German and market-based British financial system in employment terms. While in Germany banks account for two-thirds of finance professionals, in the UK they barely account for half. The insurance sector is much bigger in Germany as well, which is understandable considering Allianz, MunichRe, and HannoverRe are some of the world's largest insurance companies. Auxiliary finance, including securities and large parts of asset management industry, is incomparably larger in the UK, which does not surprise considering London's primacy in European investment banking, and that asset management in Germany is dominated by the insurance industry rather than separate, specialized asset management firms, as is the case in the UK (Burger, 2011). What the UK and Germany have in common is the rise of auxiliary finance, by $13 \%$ in the UK and $21 \%$ in Germany (figure 2). In the UK this happened at the expense of both banking and insurance, where employment fell by as much as $18 \%$ and $19 \%$ respectively, while in Germany it happened mainly at the cost of insurance, registering a 3\% fall in employment compared to only a $1 \%$ fall in banking. The boom in auxiliary finance is not surprising given that asset management has grown globally despite the crisis, being less affected by toxic debt than banks, and fuelled by a continued shift to funded pension systems and rising as well as increasingly concentrated private wealth (Beaverstock, Hall, Wainwright, 2013; Clark, Strauss, Knox-Hayes, 2012). 
What is puzzling though is how German banking has withstood the crisis with such little loss of employment?

$$
\begin{aligned}
& \text { <insert figure } 2 \text { around here> } \\
& \text { <insert figure } 3 \text { around here> }
\end{aligned}
$$

To address this question, let us consider some structural features and changes. Between 2008 and 2012 the number of bank branches in Germany declined by $8 \%$, from $39 \mathrm{k}$ to $36 \mathrm{k}$, while the UK experienced a decline of $5 \%$, from $12.3 \mathrm{k}$ to $11.7 \mathrm{k}$. In the same period the share of the top five credit institutions in total bank assets increased from $23 \%$ to $33 \%$ in Germany and from $35 \%$ to $41 \%$ in the $\mathrm{UK}^{1}(\mathrm{ECB}, 2014)$. Despite faster consolidation at institutional and branch network levels in Germany, banking in Germany lost only 1\% of employment, while in the UK as much as $18 \%$ was lost. This apparent paradox can be explained by several factors. First, Germany has a much denser bank branch network, and lower institutional concentration, which means that potential for consolidation is larger, and levels of concentration that would raise concerns of competition authorities are further away. Second, banking employment in Germany has been falling slowly but steadily since at least late 1990s in line with rationalization of branch networks (Zademach 2014), while a credit boom in the UK was accompanied by rising employment in banks in early 2000s (French, Lai, Leyshon, 2010). Total lending in Germany has leveled off since 2007, while in the UK it has contracted by nearly 30\% (ECB, 2014). Moreover, the structure of lending in Germany changed in favour of retail-oriented, labour-intensive, small local banks, with credit from savings and cooperative banks rising by $20 \%$ since

\footnotetext{
${ }^{1}$ Deutsche Bank's takeover of Postbank in 2010, and Lloyds Group's takeover of HBOS in 2009 were the largest contributors to increasing institutional concentration.
} 
2008 , and falling by $20 \%$ on the part of private banks (with Deutsche Bank, and Commerzbank in the lead) and regional banks (Landesbanken) (Gärtner and Flögel, 2014). In the UK, the losses in retail banking were augmented by those in investment banking, which plays a much bigger part in the UK than Germany (Wójcik, 2012). In Germany, with the domestic credit boom, only large banks with significant international activities were directly affected by the crisis, as they lent to debt-ridden economies of the European periphery and/or invested in US subprime assets. In short, both the home-grown and imported financial crisis has penetrated the British banking system much more widely and deeply than that of Germany. In the following section, we explore the implications of the crises on the footprint of the financial system in both countries.

\section{Impacts on financial centres and spatial concentration}

\subsection{London and Frankfurt}

There has been a lot of research on London and Frankfurt as leading financial centres, but little on the impact of the recent crises on these cities (Leyshon and Thrift, 1997; Grote, 2008; Schamp, 2009). In both cities between 2008 and 2012 financial employment grew by $2 \%$, from $354 \mathrm{k}$ to $360 \mathrm{k}$ in London, and from $73 \mathrm{k}$ to $75 \mathrm{k}$ in Frankfurt (table 1). The structure of change by subsector has been similar in both centres, with insurance suffering a large decline and auxiliary finance enjoying a large increase. The temporal pattern of change has been similar to national trends, with a faster and deeper decline in London - $9 \%$ fall in total financial employment in 2009, compared with a 1\% fall in Frankfurt only in 2010 (figure 4). Since 2010 in London and 2011 in Frankfurt, the financial sector has slowly recovered to exceed pre-crisis levels of employment. In both cities, 
the financial sector fell slightly behind total employment growth, and consequently the share of the sector in total employment fell from $7.9 \%$ to $7.8 \%$ in London, and from $15 \%$ to $14.7 \%$ in Frankfurt. Overall, the patterns of change since 2008 seem to be much more similar between London and Frankfurt than between the UK and Germany as a whole, as analysed in the previous section. This perhaps should not be surprising, considering that both financial centres are tied to the fortunes and misfortunes of large (often the same) banks with major international and investment banking activities ${ }^{2}$. As an example, Deutsche Bank's continued commitment to a global investment banking strategy, contributes to employment in London at least as much as it does in Frankfurt, as London is the centre of the Bank's investment banking operations. As such, this finding indirectly supports research on close connections and complementarity among leading financial centres, with London and Frankfurt as the financial axis of the EU (Faulconbridge, 2004, Beaverstock et al., 2001).

$<$ Insert Table 1 around here>

$<$ Insert Figure 4 around here $>$

When changes in financial capitals are related to national economies, the contrast between Germany and the UK prevails. London has increased its share of British financial employment from $31 \%$ to 34\%, while Frankfurt's share has remained almost unchanged at $7.5 \%$ (figure 5). Moreover, in the UK, employment has become more concentrated in London in every part of finance. The pattern of change between 2008 and 2012 in the UK follows the prediction of Cooper and Larkin (2008), who suggested that investment banking and

\footnotetext{
2 Top 5 banks in Frankfurt, account for more than $60 \%$ of banking employment in the city (Helaba, 2013).
} 
wholesale finance would suffer first, but then banks would start slimming balance sheets and branch networks, making regional centres (particularly small and highly specialized ones) more vulnerable. According to them, most British banks have already set up back office operations outside of London, and mounting cost pressures on banks are likely to push these operations further away to places like India. In their words "Regional centres which have seen employment rise steeply over the last five years of the credit boom could now experience equally dramatic job losses" (6). We can see this pattern in figure 5, with concentration in London falling quickly in 2009, but rising ever since.

$<$ Insert Figure 5 around here $>$

An additional factor that would have contributed to growing concentration of employment in London is hiring in compliance and risk management departments of private financial firms as well as financial regulatory agencies. London, being the only major financial command and control centre in the UK, accounts for the lion's share of this growth. In 2012 the Bank of England and the Financial Conduct Authority employed 1.5k people more than their predecessors in 2008. As large firms often outsource compliance functions, in 2013 alone London has seen the creation of over 200 specialised financial compliance companies (McGrath and McNulty, 2014). To be sure, Frankfurt has also enjoyed a boom in financial compliance and regulatory jobs. The Bundesbank has been undergoing centralization since before 2008 , though it still employs more people outside than in Frankfurt. Frankfurt also hosts an office of the Federal Financial Supervisory Authority (headquartered in Bonn), European Insurance and Occupational Pensions Authority, and the Federal Agency for Financial Market Stabilization, established in 2008. The ECB, 
assuming new power with the introduction of the EU Banking Union, is moving into new HQs and plans to employ 1000 new staff by the end of 2014.

What seems, however, more important than regulation to explaining the growing concentration of financial employment in London is the continued appeal and power of London as a global financial centre (Allen, 2010). Though not without increasing competition, it remains an undisputed hub of banking, asset management and other financial services, reflected for example in its growing share of global foreign exchange and derivatives trading (BIS, 2013). If global financial institutions have to limit themselves to one location in Europe where they can wait for the storm to end, it is highly likely to be London. In many respects the crisis, and its Eurozone version in particular, has turned London into a 'safe haven' particularly for investment by wealthy individuals and cashrich corporations withdrawing their resources from crisis-stricken economies such as Greece. Rising property prices in London clearly reflect this process (Kollewe and Neate, 2012).

\subsection{Regional financial centres}

To analyse changes in spatial concentration beyond London and Frankfurt, in table 1 and figure 4 we identify regional centres as those with financial employment in excess of 20k (excluding London and Frankfurt as national centres). This definition, covering 6 cities in the UK and 7 in Germany, is arbitrary but justified given that financial employment figures for Germany and the UK are very similar, and the fact that the $9^{\text {th }}$ and $8^{\text {th }}$ largest financial centre in Germany and UK respectively have much less employment - Nurnberg with 16k compared to Hannover's 25k, and Cardiff's 13k compared to Glasgow's 22k. While the same cities remain regional centres throughout the period in both 
countries, no change in their order in Germany contrasts with significant change in the UK, where Leeds fell from the $4^{\text {th }}$ to the $6^{\text {th }}$ place, with Birmingham rising from $5^{\text {th }}$ to $4^{\text {th }}$, and Bristol from $6^{\text {th }}$ to $5^{\text {th }}$.

Figure 4 documents a sharp increase in the spatial concentration of finance in the UK, contrasting with relative stability in Germany. Every regional centre in the UK lost employment, and in total they lost $10 \%$ of financial jobs (compared to a 2\% gain in London). Moreover, outside of London and regional centres, financial employment contracted by $13 \%$. In other words, the further down the financial hierarchy the larger the losses suffered since 2008. Subsectoral figures reveal that provincial areas in the UK were hit particularly hard by losses in banking employment, which fell by a quarter, compared to $10 \%$ in London and $12 \%$ in regional centres. In Germany, regional centres and provincial areas gained $1 \%$ in financial employment, compared to $2 \%$ in Frankfurt. In banking, provincial Germany actually suffered a lower loss in employment than Frankfurt or regional centres. Hannover, a large centre of the insurance industry, hosting the world's $3^{\text {rd }}$ largest reinsurance company ${ }^{3}$, and Berlin, where the financial sector is still arguably underdeveloped in relation to the economic and political functions of the city, saw financial employment grow faster than in Frankfurt ${ }^{4}$.

Findings on growing concentration in the UK in contrast to Germany can be corroborated by analyzing the geographical concentration index for Britain and Germany at NUTS1 level (with 11 regions in the UK, and 16 in Germany,

\footnotetext{
${ }^{3}$ Hannover hosts a research institute called Hannover Centre of Finance created in 2009, and has its own regional stock market index NISAX 20.

${ }^{4}$ Even Düsseldorf, home to IKB and WestLB, two of the German financial institutions most adversely affected by the subprime crisis, did not lose employment since 2008. Both IKB and WestLB invested significantly in subprime-mortgage related products, and both received financial support from the government and other banks (Lewis, 2011).
} 
representing Länder). In Germany, regional concentration of financial employment has declined slightly, mainly due to the insurance sector (figure 6). In the UK, regional concentration increased in every subsector of finance, particularly in banking. Regions that lost most employment were: East Midlands (24\% loss); North East (20\%), including Newcastle, the home of Northern Rock, which suffered a bank run in 2007; East (18\%); and Yorkshire and the Humber (17\%), including Leeds, and home to Bradford and Bingley, nationalized and sold to Santander Group in 2008. Regions with lowest losses outside of Greater London were: South West (4\%), including Bristol; South East (8\%); and West Midlands (8\%), including Birmingham. Thus, while the South did not share the recovery of financial employment with London, at least it has retained its share of British finance, while regions further north mostly lost it. Proximity to London also appears to have helped the West Midlands including Birmingham, which hosts a $2 \mathrm{k}$ person strong office of Deutsche Bank, and some headquarter functions of Lloyds Group 5 .

\section{$<$ Insert Figure 6 around here $>$}

Scotland is an interesting case in its own right, reproducing the patterns of growing concentration at the national level. As a whole Scotland lost $13 \%$ (14k) of financial jobs, but the distribution of losses has been highly uneven. While Edinburgh lost 0.5k jobs, Glasgow lost 5.5k (20\%), and the rest of Scotland lost 8k (21\%). As a result, Edinburgh's share in Scottish financial employment grew from $37 \%$ to $42 \%$, and from $57 \%$ to $70 \%$ in insurance. Thus, despite being home to HBOS and RBS, two of the banks most adversely affected by the

\footnotetext{
${ }^{5}$ The Birmingham operation of DB focuses on back office but includes front office services for small corporate customers, including a new trading floor. This is the first significant front-office operation by an investment bank in the UK outside of London (Turner, 2014).
} 
subprime crisis, Edinburgh has weathered the crisis much better than the rest of Scotland, and better than any British financial centre with the exception of London and Birmingham. Edinburgh remains a major centre of insurance and asset management, hosting financial jobs with higher-levels of skill compared with more back and mid-office oriented jobs in other regional centres, and Glasgow in particular (TheCity UK, 2013). Adding the long history of Edinburgh as a financial centre to the argument, arguably its finance professionals come from wealthier backgrounds, and even if laid off by large institutions, they are more likely to weather the crisis within the sector, by setting up their own advisory and other companies, rather than leave in search of other jobs. While Edinburgh has lost ground to London since 2008, it has slightly consolidated its position as the second financial centre of the $\mathrm{UK}^{6}$. In loose terms, Edinburgh might even be characterized as a small version of Munich, the second German financial centre, the leading insurance centre in the country, and the capital of a wealthy regional economy (Klagge and Peter, 2011).

To summarise, we have documented the process of growing concentration in financial employment in the UK at both the regional level and across the financial centre hierarchy, which contrasts with the continued significance of regional and lower-tier financial centers in Germany. In the British financial system, affected widely and deeply by the recent boom and bust, major job cuts, particularly in banking, weakened regional and local centres, while employment in London has more than recovered, boosted by institutional

\footnotetext{
${ }^{6}$ Edinburgh rose to this position slowly. Leyshon, Thrift and Tommey (1989) ranked Edinburgh $5^{\text {th }}$ behind London, Manchester, Birmingham and Glasgow according to employment in 1981, but show that by 1984 Edinburgh took over Glasgow. According to financial functions, Parr and Budd (2000) still classify Edinburgh as a $3^{\text {rd }}$ tier centre, with Birmingham, Glasgow, and Manchester as $2^{\text {nd }}$ tier.
} 
consolidation in banking (with London headquartered banks taking over failed institutions), and a boom in auxiliary financial jobs including compliance and asset management, the latter responding mainly to growing foreign demand for wealth management and other services. In Germany, Frankfurt has also benefited from growing consolidation (with Helaba taking over WestLB, and DB taking over Postbank) and a rise of compliance jobs. These centripetal forces, however, have been offset by the role of regional and local banks, which were partly sheltered from the boom and bust of international wholesale markets, and which have expanded their lending activities, in the process preserving the regionalized structure of German finance.

\section{Conclusions and implications}

This paper used employment data to investigate the development of the British and German financial sector since 2008. For Germany, we found a slight increase in financial employment, a slight decrease in the share of finance in total employment, and hardly any change in the spatial distribution of financial employment. The UK meanwhile has seen an 8\% drop in financial employment, a significant decrease in its share in total employment, and a considerable growth in the concentration of financial employment in London at the expense of regional centres, with the rest of the UK affected even more adversely. We would suggest that this is the largest drop in financial employment and the largest increase in its spatial concentration in the UK for at least four decades. Previous geographical research shows the rise of provincial centres from 1974 to 1984 (Leyshon, Thrift and Tommey, 1989); the boom in financial employment across the country, particularly in the South of England (excluding London) of the late 
1980s followed by a short contraction in the early 1990s (Leyshon and Thrift, 1997); and resumed growth from the mid-90s until 2006, accompanied by the rise of regional centres such as Edinburgh, Leeds and Bristol (French, Lai, Leyshon, 2010). Studying failures of regional financial institutions since 2007, Marshall described the recent crisis as an "the culmination of a further round of centralization reinforcing established processes distorting the British space economy" $(2013,472)$. Research on previous rounds, including the early-90s recession, has also focused on growing concentration of control functions in the British financial sector in London. Our contribution is to show that this time, growing spatial concentration affects not only command and control over the financial sector, but also employment, and applies across financial subsectors, with London, not the South of England or any regional centre, as the sole winner thus far.

The documented changes in British finance are dramatic enough to question the expectation of strong inertia in financial centre development. Decline in the share of finance in total employment of 0.2 percentage points, and increase in the share of London by 3 percentage points may seem unimpressive, but employment losses of $20 \%$ or more in many cities are large, and unlikely to be reversed quickly if at all. The most important theoretical contribution of the paper is on the significance of the institutional structure of financial systems for their changing geography and response to crises in particular. The prominence of regional and local banks in the German system, underpinned by a decentralized state, has sheltered a large part of German finance from the influence of an external shock transmitted mainly through international financial markets. In the process, it has also prevented a round of spatial concentration of 
financial employment, even if concentration of financial command and control functions increased through (often forced) mergers and acquisitions. In line with studies of complexity and resilience, one might even argue that the position of regional and local banks has made the German financial system more heterogeneous, diverse and therefore more resilient to the crises (Haldane and May, 2011). We do not want to overstate the conclusion on resilience, however, considering that the Eurozone crisis lingers on, and the situation in Germany might be a silence before a storm. Witness for example, the risky strategy of Deutsche Bank, delaying radical cost cutting and betting on a quick market recovery in contrast to most of its European competitors.

The growing spatial concentration of finance in the UK seems to be reinforced by the government's response to the crisis. This happens through forced acquisitions of provincial firms by London-based institutions, but also through the growth of compliance and other employment related to regulation, which is heavily concentrated in London. In Germany, this trend is offset partly by regionalization of financial regulation, and by the position of regional and local banks. One broader implication here is that new regulation, which is erecting barriers between national financial systems, may lead to centralization and concentration of financial activity within countries, though national and regional institutions, as they did thus far in Germany, can moderate such impacts. Historically, it is not the first time that regulation has led to centralization and concentration. In the USA, for example, regulation introduced in 1930s, after the Great Crash, unleashed a major concentration of US stock market activity in New York (Wójcik, 2011). What is frustrating in the current context is that historical lessons are lost on policy makers, with little or no recognition of the spatial 
consequences of the crisis and government response to it acting as "accidental regional policy" (French, Lai, Leyshon, 2010, 77). We found no mention of geography in Bank of England documents, ECB documents, or the EU and UK government reports on the impacts of the financial crisis. The Bank of England reports are full of analysis on international financial flows affecting the British financial system, but no consideration of its geography at the subnational level. As Marshall $(2013,19)$ argued "Re-regulating the banks is not just about making them more stable following the crash of 2007-2009; it is about using the opportunity of reform to rebalance the space economy." Thus far, barring some nostalgia for small, local banks expressed in media7, and regional banking featuring on the list of Labour's policies for 2015 elections, we see no serious consideration of this issue in the UK.

The paper has important implications for developing and emerging economies building their financial systems. In China for example, the financial system is still highly fragmented and regionalized, but institutional consolidation and geographical concentration are on the rise (Yeung, He, Liu, 2012). If more regionalized financial systems indeed offer more resilience, as this comparative case study suggests, the Chinese government may be advised to retain some protection of local and regional financial institutions against centripetal forces, even if that happens at the expense of financial system efficiency. To be more conclusive, however, our study would have to be extended to more countries, to allow a more comprehensive analysis on how the institutional structure of financial systems affects their response to financial crises. In addition to

\footnotetext{
7 In 2012 Channel 4 broadcast a series 'Bank of Dave' presenting an entrepreneur David Fishwick who set up a new local bank in Burnley, using German local banks as one of his models and sources of inspiration. See Fishwick, 2014.
} 
employment, further research should also consider the impact of crises on the geography of credit creation, including access of small and medium sized firms to funding.

\section{References}

Allen, J. (2010) The City and finance: changing landscapes of power. In N.M. Coe and A. Jones (eds), The Economic Geography of the UK. London: Sage, 49-60.

Arnold, M., Sharman, A. (2014) Barclays cuts 7,000 jobs in investment banking retreat, Financial Times, 9 May, 1.

Bassens, D., van Meeteren, M., Derudder, B., Witlox, F. (2013) No more credit to Europe? Cross-border bank lending, financial integration, and the rebirth of the national scale as a credit scorecard. Environment and Planning A, 45: $2399-2419$

Beaverstock, J.V., Hall, S., Wainwright, T. (2013) Servicing the super-rich: new financial elites and the rise of private wealth management retail ecology. Regional Studies, 47: 834-849.

Beaverstock, J.V., Hoyler, M., Pain, K., Taylor, P.J. (2001) Comparing London and Frankfurt as world cities: A relational study of contemporary urban change. Anglo-German Foundation for the Study of Industrial Society, https://dspace.lboro.ac.uk/dspace-jspui/handle/2134/9572.

BIS (2013) Triennial Central Bank Survey. Bank for International Settlements, http://www.bis.org/publ/rpfx13fx.pdf.

Burger, C. (2011) Adoption patterns of occupational pensions in Germany. Environment and Planning A, 43: 2666-2687. 
Cassis, Y. (2006) Capitals of Capital: A History of International Financial Cenres, 1780-2005. Cambridge: Cambridge University Press.

Clark, G.L. (2000) Pension Fund Capitalism. Oxford: Oxford University Press.

Clark, G.L., Strauss, K., Knox-Hayes, J. (2012) Saving for Retirement: Intention, Context, and Behavior. Oxford: Oxford University Press.

Clark, G.L., Wójcik, D. (2007) The Geography of Finance: Corporate Governane in a Global Marketplace. Oxford: Oxford University Press.

Cooper, M., Larkin, K. (2008) Financial services in Britain's cities: Weathering the storm? Centre for Cities, http://centreforcities.customer.meteoric.net/weatheringthestorm.html.

Dixon, A.D. (2012) Function before form: macro-institutional comparison and the geography of finance. Journal of Economic Geography, 12: 579-600.

Dunkley, E. (2014) Lloyds cuts 9000 jobs and shuts 200 branches in digital pursuit. Financial Times, 29 October, 1.

Engelen, E., Grote, M.H. (2009) Stock exchange virtualization and the decline of second-tier financial centres - the cases of Amsterdam and Frankfurt, Journal of Economic Geography, 9: 679-696.

European Central Bank (2014) Statistical data warehouse. http://sdw.ecb.europa.eu.

Faulconbridge, J. (2004) London and Frankfurt in Europe's evolving financial centre network. Area, 36: 235-244.

Fishwick, D. (2012) Why I opened a 'bank'. Huffington Post. http://www.huffingtonpost.co.uk/david-fishwick/bank-of-dave-why-iopened-it_b_1664967.html. 
French, S., Lai, K., Leyshon, A. (2010) Banking on financial services. In N.M. Coe and A. Jones (eds), The Economic Geography of the UK. London: Sage, 61-78.

Fujita, M., Krugman, P., Venables, A.J. (1999) The Spatial Economy: Cities, Regions and International Trade. Cambridge, MA: MIT Press.

Gerschenkron, A. (1962) Economic Backwardness in Historical Perspective: A Book of Essays. Cambridge, MA: Belknap.

Gärtner, S., Flögel, F. (2014) Call for a spatial classification of banking systems through the lens of SME finance - decentralized versus centralized banking in Germany as an example. Institute for Work and Technology, Westphalian University of Applied Sciences, Discussion Paper 14/01, http://papers.ssrn.com/sol3/papers.cfm?abstract_id=2446822.

Grote, M.H. (2008) Foreign banks' attraction to the financial centre Frankfurt an inverted 'U'-shaped relationship. Journal of Economic Geography, 8: 239-58.

Grote, M.H., Lo, V., Harrschar-Ehrnborg, S. (2002) A value-chain approach to financial centres - the case of Frankfurt. TESG Journal of Economic and Social Geography, 93: 412-423.

Haldane, A.G., May, R.M. (2011) Systemic risk in banking ecosystems. Nature, 469: 351-355.

Hall, P.A., Soskice, D. (eds) (2001) Varieties of Capitalism: The Institutional Foundations of Comparative Advantage. Oxford: Oxford University Press.

Helaba (2013) Financial centre focus: The largest banks in Frankfurt financial centre. Volkswirtschaft/Research, 8 November, https://www.helaba.de/de/DieHelaba/MaerkteUndAnalysen/ResearchUndV olkswirtschaft/FinanzplatzFrankfurt. 
Helaba (2010) Moderater Personalabbau in Frankfurts Banken. Helaba Volkswirtschaft/Research, 25 May. https://www.helaba.de/de/DieHelaba/MaerkteUndAnalysen/ResearchUndV olkswirtschaft/FinanzplatzFrankfurt/FinanzplatzFrankfurtArchiv.html.

Hendrikse, R.P., Sidaway, J.D. (2014) Financial wizardry and the Golden City: tracking the financial crisis through Pforzheim, Germany. Transactions of the Institute of British Geographers, 39: 195-208.

Hoyler, M. (2011) External relations of German cities through intra-firm networks - a global perspective. Raumforschung und Raumordnung, 69: 147159.

International New York Times (2014) Frankfurt: Center of Finance. International New York Times, 20 May, I-II.

Klagge, B., Peter, C. (2011) Changes in the German urban system - a financial sector perspective. Raumforschung und Raumordnung, 69: 201-211.

Klagge B., Martin, R. (2005) Decentralized versus centralized financial systems: is there a case for local capital markets? Journal of Economic Geography, 5: $387-421$.

Kollewe, J., Neate, R. (2012) London property offers stable investment for wealthy Europeans. The Guardian, 1 June, http://www.theguardian.com/uk/2012/jun/01/london-property-stableinvestment-europeans.

La Porta, R., Lopez-de-Silanes, F., Shleifer, A., Vishny, R.W. (1998) Law and finance. Journal of Political Economy, 106: 1113-55.

Lewis, M. (2011) Boomerang: The Meltdown Tour. London: Allen Lane. 
Leyshon, A., Thrift, N. (1997) Money/Space. Geographies of Monetary Transformation. London: Routledge.

Leyshon, A., Thrift, N., Tommey, C. (1989) The rise of the British provincial financial centre. Progress in Planning, 31: 151-229.

Marshall, J.N. (2013) A geographical political economy of banking crises: a peripheral region perspective on organizational concentration and spatial centralization in Britain. Cambridge Journal of Regions, Economy and Society, 6: 455-477.

Marshall, J.N., Pike, A., Pollard, J.S., Tomaney, J., Dawley, S., Gray, J. (2012) Placing the run on Northern Rock. Journal of Economic Geography, 12: 157-181.

Martin, I. (2013) Making It Happen: Fred Goodwin, RBS and the Men Who Blew Up the British Economy. London: Simon and Schuster.

Martin, R. (2011) The local geographies of the financial crisis. Journal of Economic Geography, 11: 587-618.

McGrath, J. (2014) Salaries sizzle as competition heats up for compliance staff, Financial News, 2 June, 1.

McGrath, J., McNulty, L. (2014) Compliance rules trigger bonanza for consultants, Financial News, 9 June, 2.

Mishkin, F.S. (2007) The Economics of Money, Banking, and Financial Markets. Boston, MA: Pearson.

Möller, J. (2010) The German labor market response in the world recession - demystifying a miracle. Zeitschrift für Arbeitsmarktforschung, 42: 325-336.

Parr, J.B., Budd, L. (2000) Financial services and the urban system: an exploration. Urban Studies, 37: 593-610.

Schäfer, D., Ross, A. (2014) Deutsche’s gamble, Financial Times, 21 May, 11. 
Schamp, E. (2009) Das Finanzzentrum - ein Cluster? Zeitschrift für Wirtschaftsgeographie, 53: 89-105.

Stockhammer, E. (2011) Peripheral Europe's debt and German wages: the role of wage policy in the Euro area. International Journal of Public Policy, 7: 83-96.

The Economist (2014) Now you see them ..., The Economist, 21 June, 33.

The Economist (2014b) The balkanisation of banking, The Economist, 1 March, 21.

Turner, M. (2014) The future of investment banking is ... Birmingham, Financial News, 30 June, 1.

Verdier, D. (2002) Moving Money: Banking and Finance in the Industrialized World. Cambridge: Cambridge University Press.

Volgman, K. (2014) Entwicklung metropolitaner Funktionen im polyzentralen deutschen Städtesystem - Raummuster der Konzentration und funktionalen Spezialisierung. Raumforschung und Raumordnung, 72: 21-37.

Warf, B., Cox, J.C. (1996) Spatial dimensions of the savings and loan crisis. Growth and Change, 27: 135-155.

Wójcik, D. (2012) The end of investment bank capitalism? An economic geography of financial jobs and power. Economic Geography, 88: 345-368.

Wójcik, D. (2011) The Global Stock Market: Issuers, Investors, and Intermediaries in an Uneven World. Oxford: Oxford University Press.

Wright, B. (2014) Don't ignore London bankers who have cried wolf before. Financial News, 24 March, 7.

Yeung, G., He, C., Liu, H. (2012) Centralization and Marginalization: The Chinese Banking Industry in Reform. Applied Geography, 32 (2): 854-867.

Zademach, H.-M. (2014) Finanzgeographie. Darmstadt: WBG. 
Zagelmeyer, S., Heckmann, M., Kettner, A. (2012) Management responses to the global financial crisis in Germany: adjustment mechanisms at establishment level. The International Journal of Human Resource Management, 23: 33553374.

Z/Yen (2014) The Global Financial Centres Index 15, Z/Yen, http://www.zyen.com/research/gfci.html.

Z/Yen (2014b) The Global Financial Centres Index 16, Z/Yen, http://www.longfinance.net/programmes/fcf/910.html

Zysman, J. (1983) Governments, Markets, and Growth: Financial Systems and the Politics of Industrial Change. Ithaca: Cornell University Press. 
Figure 1. Change in employment and GDP $(2008=100)$

Germany
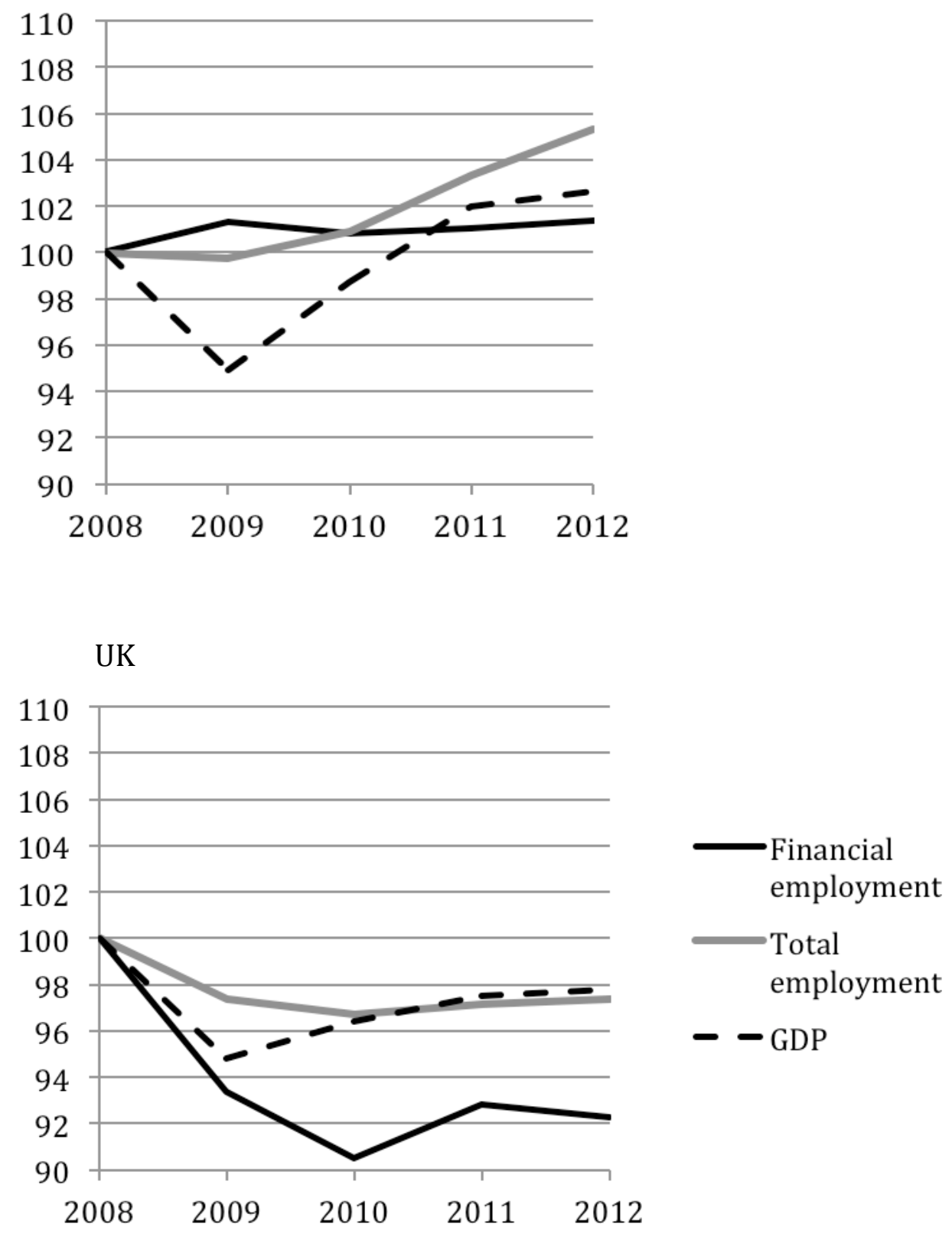

Source: Authors based on data from Bundesagentur für Arbeit, Business Register and Employment Survey of the ONS (for all figures and tables), and the World Bank. 
Figure 2. Change in employment in financial subsectors $(2008=100)$
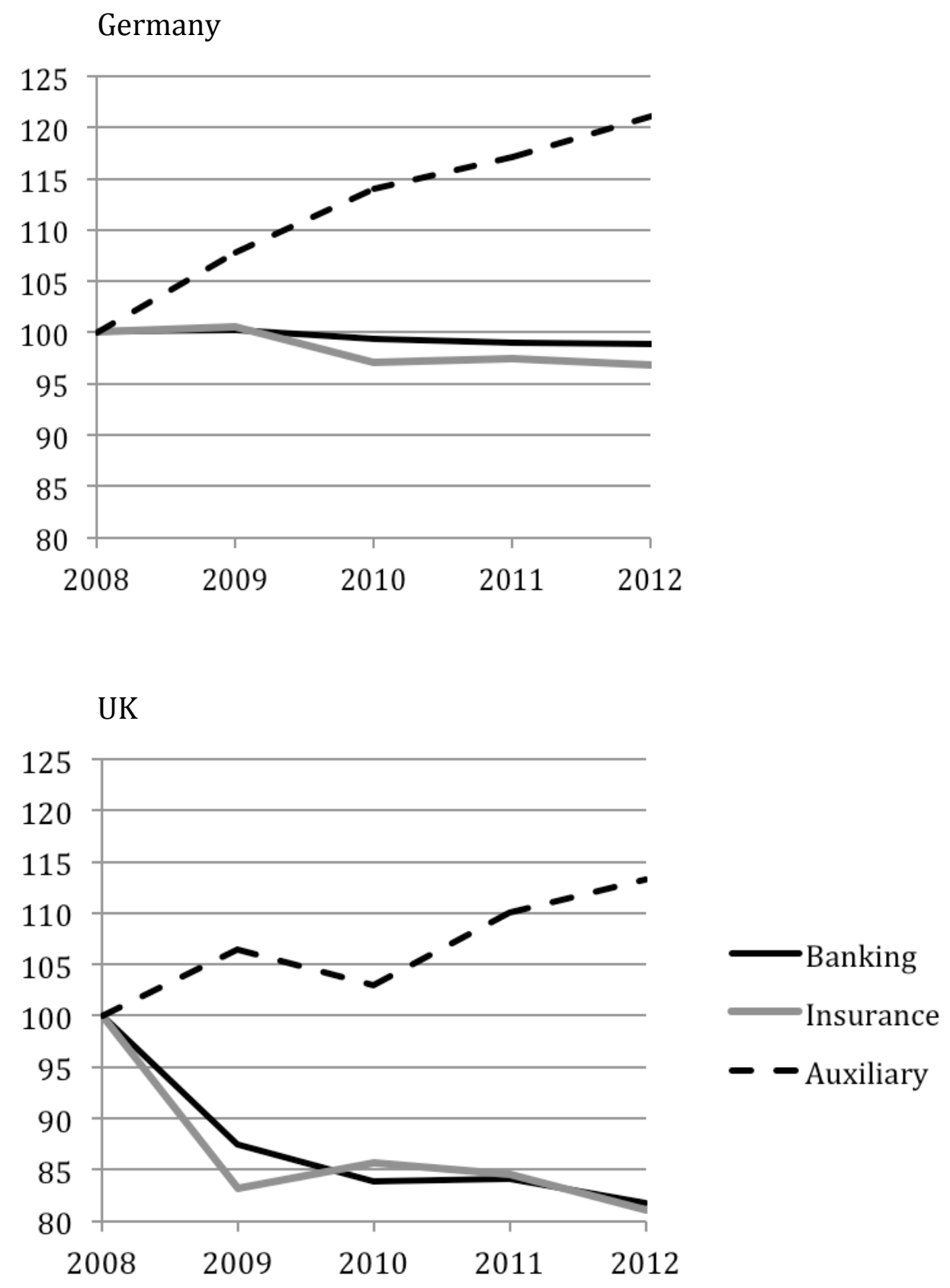

Source: Authors based on data from Bundesagentur für Arbeit, Business Register and Employment Survey of the ONS (for all figures and tables), and the World Bank. 
Figure 3. Structure of employment in the financial sector

Germany

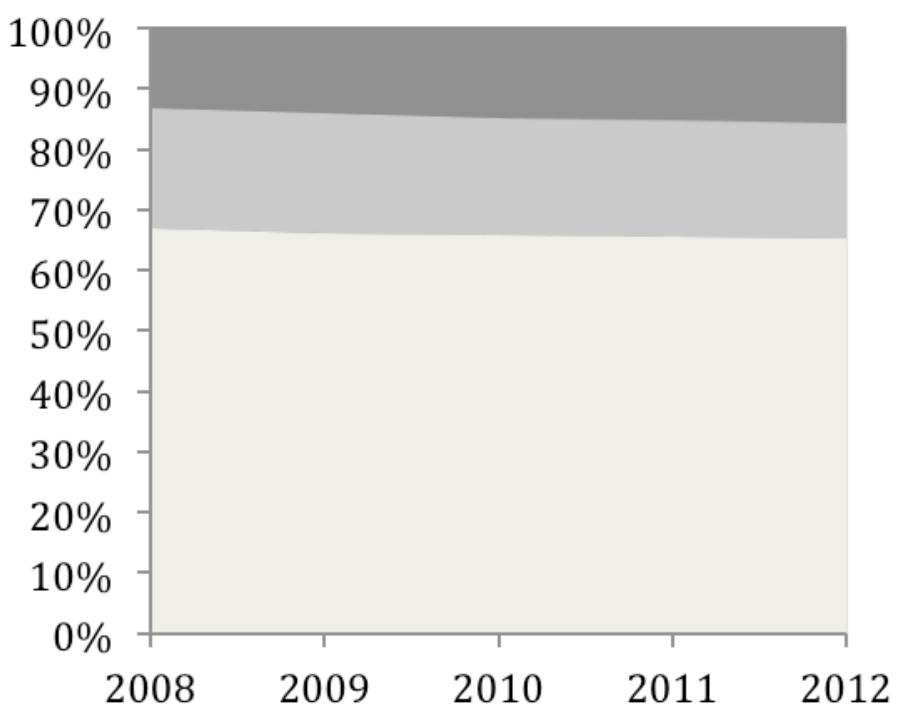

UK

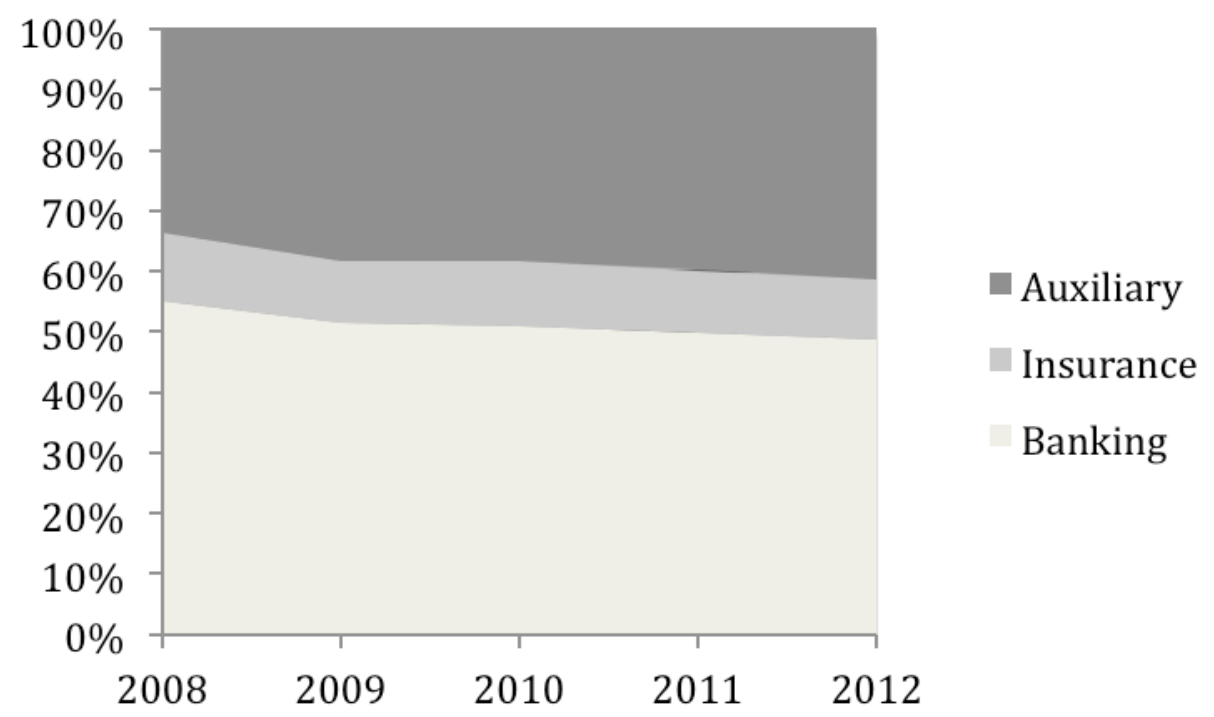


Table 1. Financial sector employment in leading centres (in thousands)

\begin{tabular}{|c|c|c|c|c|c|c|c|c|}
\hline \multirow[b]{2}{*}{ Germany } & \multicolumn{4}{|l|}{2008} & $\begin{array}{l}2012 \\
\text { Banking } \\
\end{array}$ & Insurance & Auxiliary & Finance \\
\hline & & & & & & & & \\
\hline Frankfurt & 57.7 & 6.1 & 9.4 & 73.2 & 56.8 & 5.7 & 12.4 & 74.8 \\
\hline Munich & 28.7 & 21.0 & 7.8 & 57.5 & 26.1 & 22.3 & 10.2 & 58.7 \\
\hline Hamburg & 24.4 & 18.8 & 5.4 & 48.6 & 25.1 & 17.2 & 6.8 & 49.0 \\
\hline Cologne & 13.4 & 22.5 & 4.9 & 40.8 & 12.3 & 21.6 & 6.2 & 40.1 \\
\hline Berlin & 20.3 & 5.3 & 7.9 & 33.5 & 20.1 & 5.4 & 9.4 & 34.8 \\
\hline Düsseldorf & 19.8 & 9.4 & 2.8 & 32.0 & 20.0 & 6.5 & 5.8 & 32.2 \\
\hline Stuttgart & 15.9 & 9.8 & 5.2 & 30.9 & 15.2 & 9.1 & 5.3 & 29.6 \\
\hline Hannover & 11.2 & 8.1 & 2.8 & 22.2 & 11.5 & 8.4 & 5.1 & 25.0 \\
\hline UK & & & & & & & & \\
\hline London & 195.2 & 19.4 & 139.8 & 354.4 & 175.1 & 17.1 & 167.9 & 360.0 \\
\hline Edinburgh & 18.9 & 9.3 & 10.1 & 38.4 & 19.3 & 9.1 & 9.5 & 38.0 \\
\hline Manchester & 17.3 & 8.6 & 10.2 & 36.1 & 13.6 & 4.4 & 16.1 & 34.1 \\
\hline Birmingham & 15.8 & 3.1 & 11.5 & 30.4 & 15.7 & 2.9 & 11.7 & 30.3 \\
\hline Bristol & 11.1 & 6.1 & 11.2 & 28.5 & 11.5 & 3.8 & 9.7 & 25.1 \\
\hline Leeds & 17.8 & 1.3 & 11.8 & 30.9 & 14.2 & 0.7 & 9.2 & 24.1 \\
\hline Glasgow & 15.5 & 3.0 & 9.4 & 27.9 & 10.3 & 2.0 & 10.0 & 22.3 \\
\hline
\end{tabular}

Note: Following French, Lai and Leyshon (2010) local authority districts are used for British cities except for London, defined as Greater London, Birmingham including Solihull, Bristol including South Gloucestershire, and Manchester including Salford and Trafford. German cities are defined as Kreise or kreisfreie Städte.

Figure 4. Change in financial sector employment $(2008=100)$ 


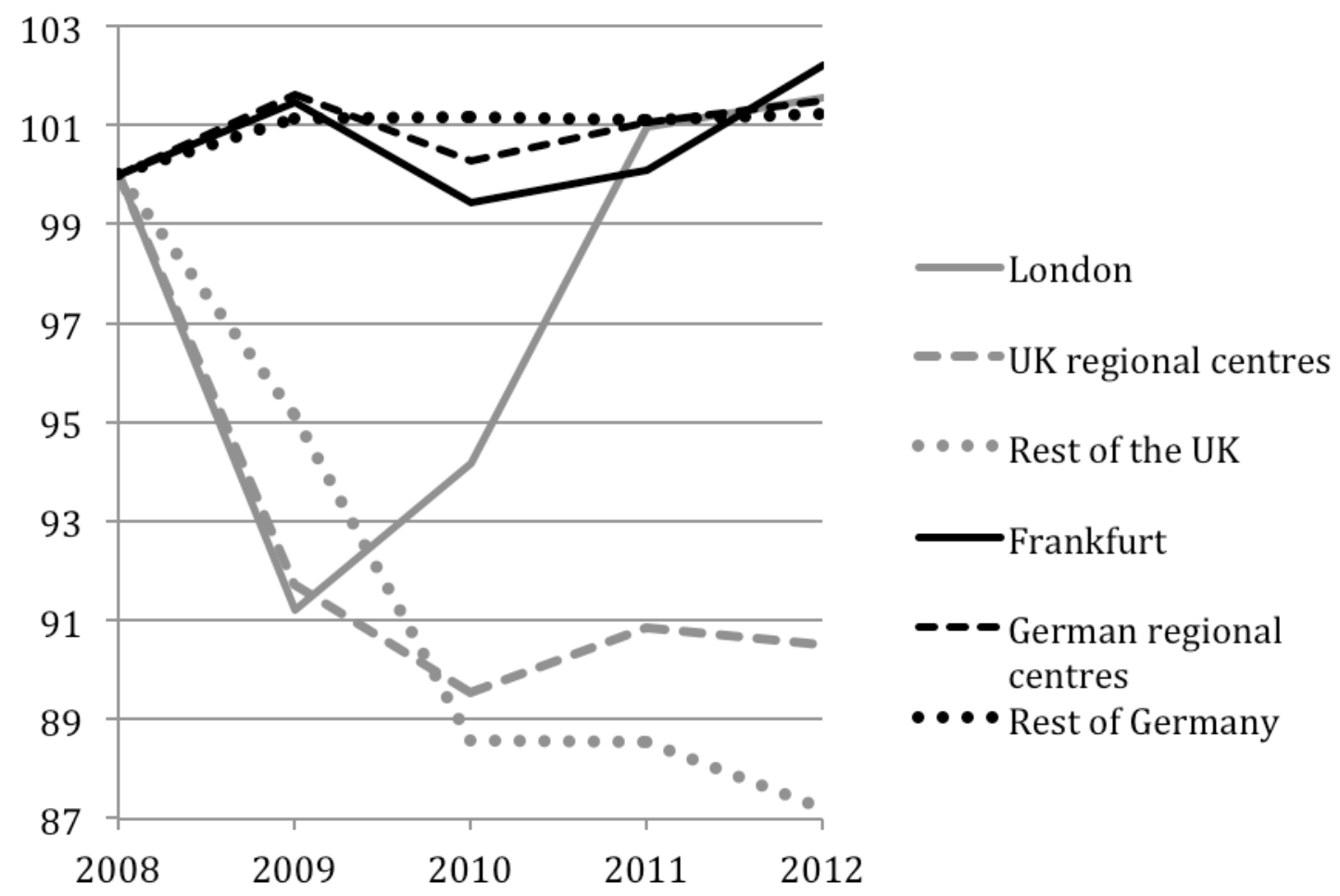

Figure 5. Share in national employment (\%)

Frankfurt

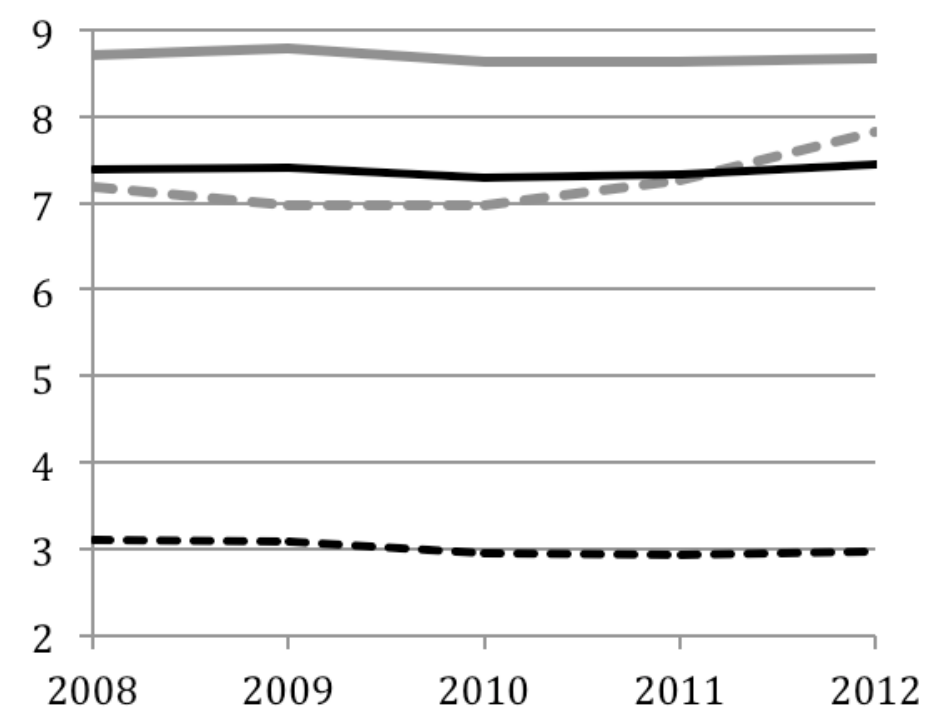

London 


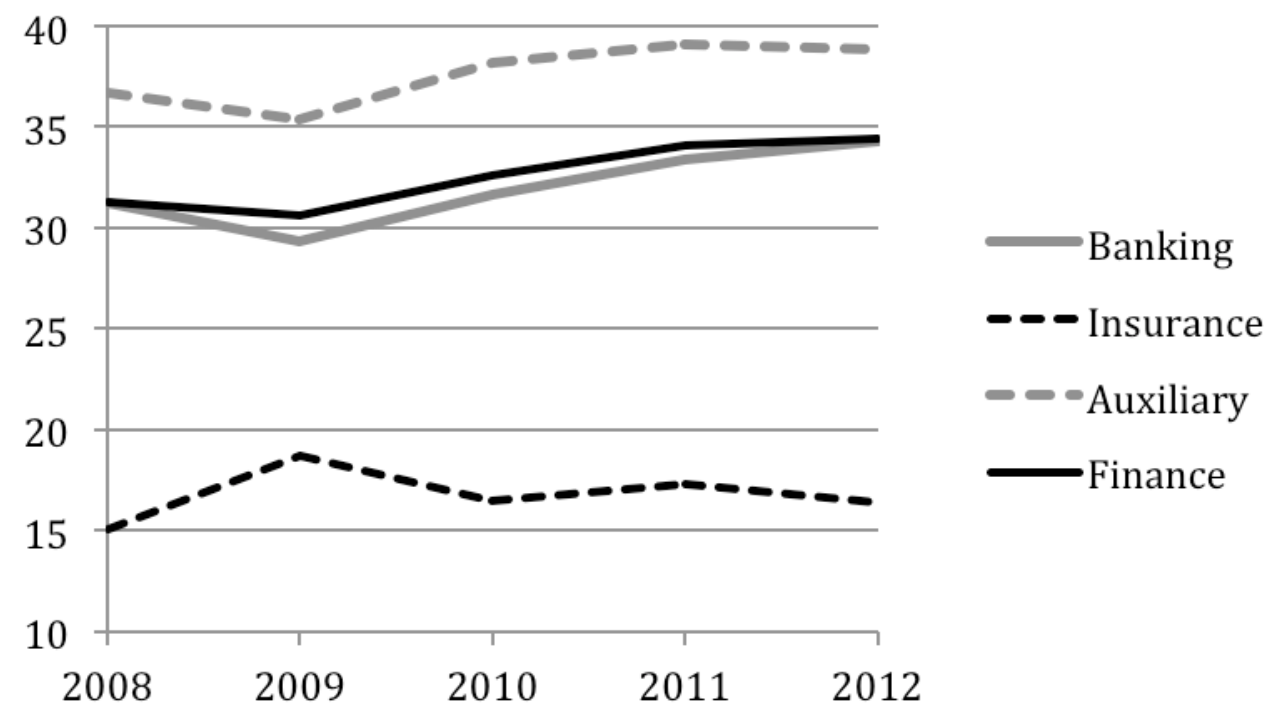


Figure 6. Geographical concentration of employment

Germany

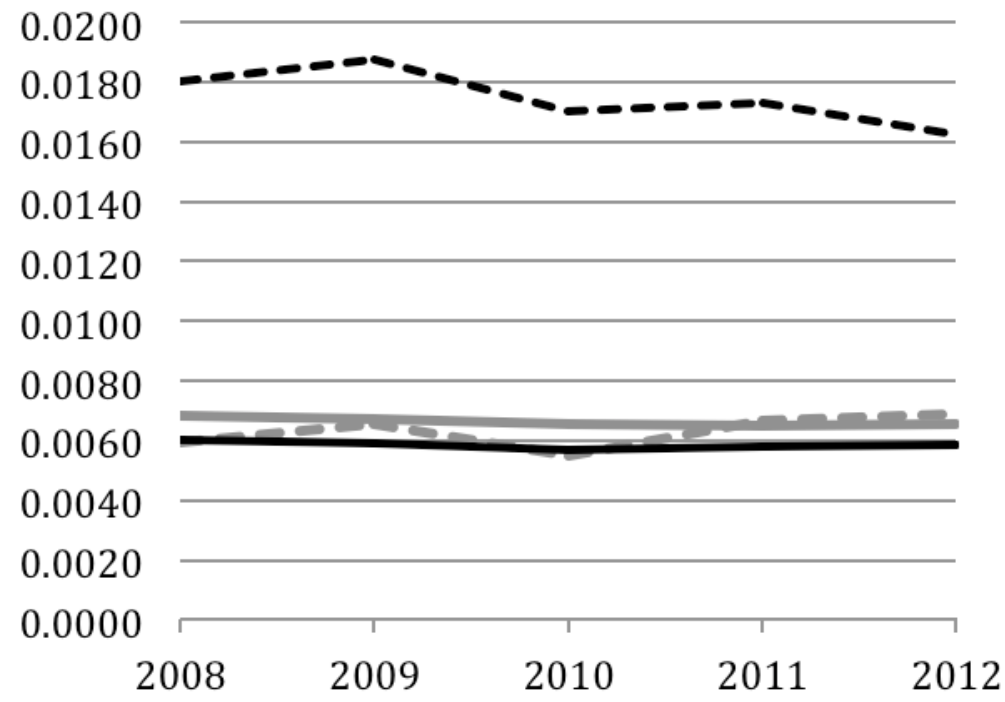

UK

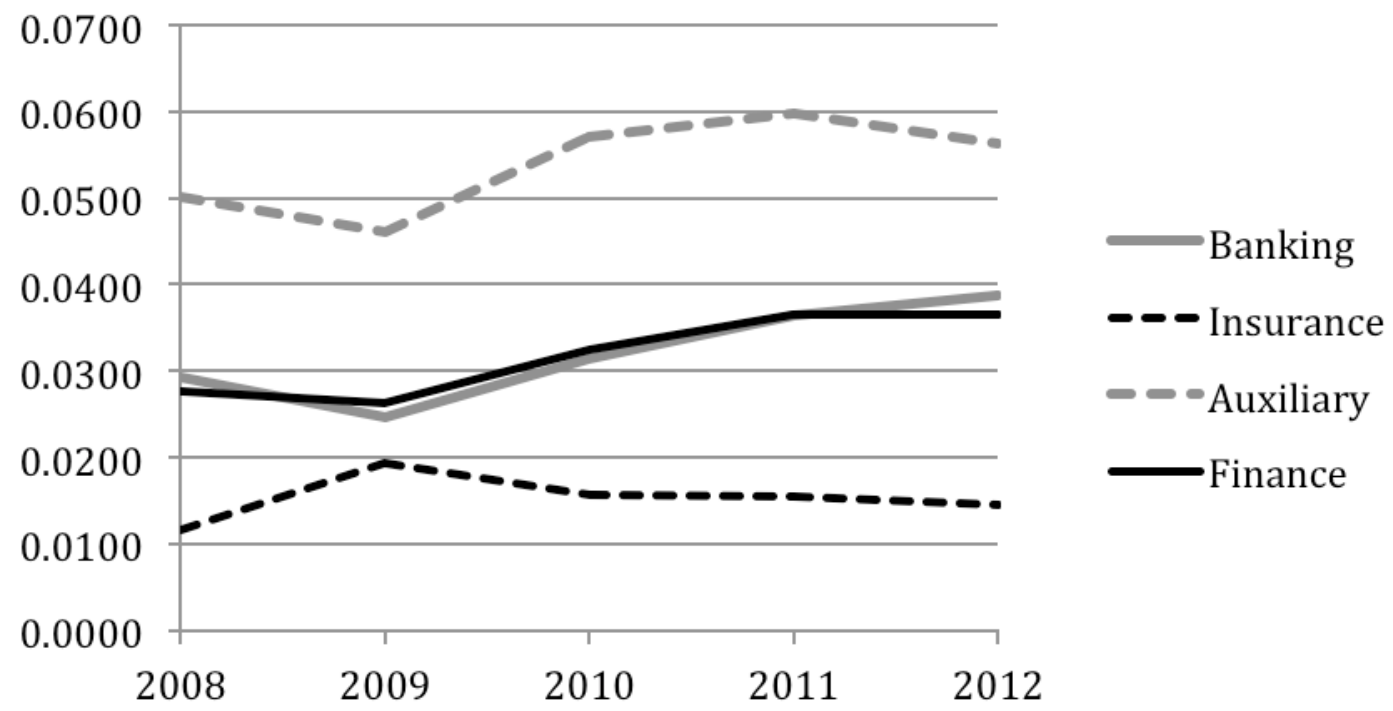

Note: The geographical concentration index is calculated as:

$$
C=\sum_{i=1}^{N}\left(x_{i}-s_{i}\right)^{2}
$$

Where $i$ stands for a NUTS1 region; $N$ for the total number of regions (16 in Germany, 11 in the UK); $x$ - the fraction share of the region, out of 1 for all regions, in employment (in banking, insurance, auxiliary finance, and finance in total); and $s$ - the fraction share of the region in total employment across all sectors. 